\title{
Reuse of waste bricks: a new generation of geopolymer bricks
}

\author{
Nicolas Youssef ${ }^{1,2} \mathbb{2} \cdot$ Andry Zaid Rabenantoandro $^{1} \mathbb{C} \cdot$ Zakaria Dakhli $^{1} \mathbb{D} \cdot$ Christophe Chapiseau $^{3} \cdot$ \\ François Waendendries ${ }^{4} \cdot$ Fadi Hage Chehade ${ }^{2}$ (D) Zoubeir Lafhaj ${ }^{1}$ (I)
}

(c) Springer Nature Switzerland AG 2019

\begin{abstract}
In this study, the potential for reuse of waste brick (WB) by alkaline activation in a new geopolymer brick was examined. The effect of the incorporation of ground granulate blast furnace slag (GGBFS), the molarity of sodium hydroxide ( $\mathrm{NaOH}$ ) and the silicate to sodium hydroxide ratio $\left(\mathrm{Na}_{2} \mathrm{SiO}_{3} / \mathrm{NaOH}\right)$ on the mechanical properties of the final product was investigated. The manufacturing of geopolymer bricks was carried out by mixing WBs, GGBFS, sand with a solution of hydroxide and sodium silicate. The samples were prepared according to different formulations. The optimal compressive strength obtained is $89.91 \mathrm{MPa}$, for a GGBFS/WB ratio of $80 / 20$, an $8 \mathrm{M}$ molarity of $\mathrm{NaOH}$ and a silicate/hydroxide ratio of 2/1. This study shows an effective feasibility for the recovery and recycling of industrial waste into a valuable product for the construction sector. This recycling method can bring environmental and economic benefits by using it as an alternative material to fired brick in construction. Given the results obtained, it will be interesting to study the environmental and economic impact as well as the durability properties of these geopolymer bricks.
\end{abstract}

\section{Graphical abstract}

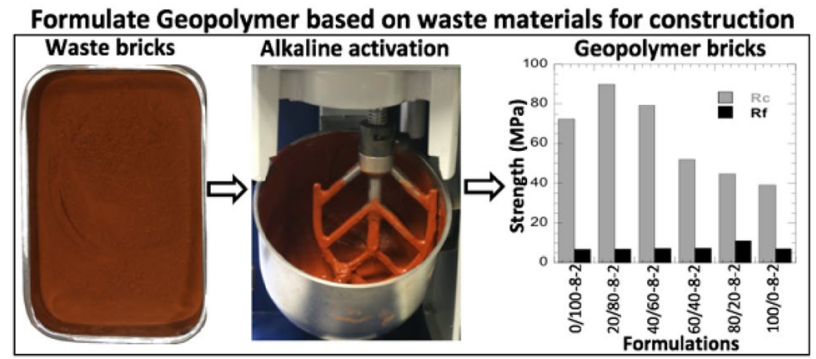

Keywords Geopolymer · Recovery of waste bricks · GGBFS · Reuse · Alkaline activation · Compressive strength

\section{Introduction}

The brick is one of the most widely used masonry units for building construction [1]. Common building materials, such as bricks and cement, are responsible for a number of sensitive issues linked to the social and environmental impacts [2]. Conventional bricks are made from raw materials, clay, sand, plastic [high-density polyethylene (HDPE) and polyethylene (PE)] and nonplastic materials, then fired in a kiln at a temperature ranging from 850 to $950{ }^{\circ} \mathrm{C}[3,4]$. The use of fossil fuels induces large energy consumptions that are responsible

$\triangle$ Zoubeir Lafhaj, zoubeir.lafhaj@centralelille.fr | ${ }^{1}$ Centrale Lille, Civil Engineering, Cité Scientifique, CS 20048, 59651 Lille, France. ${ }^{2}$ Doctoral School of Sciences and Technology, Lebanese University, Beirut, Lebanon. ${ }^{3}$ Briqueterie du Nord de la France (BdN), Port Fluvial, 59000 Lille, France. ${ }^{4}$ MINEALITHE, Rue du Moulin, 02240 Sissy, France. 
for economic, energy, environmental and ecological issues [2]. As an example, the production of one tonne of cement requires the consumption of 1.7 tons of raw materials [2] and involves the emission of 0.8 tons of $\mathrm{CO}_{2}$ into the atmosphere [5]. However, during the industrial production phase, a significant percentage of waste such as fly ash (FA), waste bricks (WB), ground granulated blast furnace slag (GGBFS) is obtained [6]. These wastes result in environmental challenges. The process of recycling and recovering a large amount of waste bricks has become necessary to ensure environmental protection [7].

In 2012, information gathered from 40 countries from six continents around the world showed a critical value of overall construction and demolition waste production that reached more than 3.0 billion tonnes [8] adding an annual production of 500 billion tonnes of blast furnace slag [9] with an increasing trend due to country development.

In France, a huge quantity of fired bricks is produced each year and used in construction activities. The amount of waste brick represents about 3-7\% by weight of total production, suggesting that millions of tonnes of waste bricks are produced and disposed of each year in huge landfill areas at brickworks. In the case of the Briqueterie du Nord (BdN), all the waste of bricks or material before firing is directly reused in production line. Waste after firing does not exceed $5 \%$ of weight production.

Depending on the characteristics of the waste, including its colour (red or other), it is sold to a clay manufacturing and distribution company (specific to the Templeuve plant in North of France). The portion of this non-red waste is either resold for construction sites in need of hard backfill or used at the quarry to stabilize the runways during winter and wet periods.

The Reuse of this industrial waste by recycling it into new building materials is considered a practical solution for reducing many environmental problems related to pollution. However, this waste can only be recycled if its environmental properties and behaviors complies with specific requirements and respond to a relevant environmental standards [10].

Many studies have been done to incorporate fired clay waste bricks into the production process of different building materials, one of these technique is the geopolymerization [11-14].

Geopolymerization is one of the best techniques of recycling waste in the production of a new construction material that meets both standards and practice-oriented applications [15].

Geopolymerization is the processing technique used to produce new geopolymer-based materials. Geopolymers are alkaline aluminosilicate binders, which can be a substitute for building materials [15].
The term Geopolymer is used to characterize a classification of alumino-silicate materials manufactured mainly for the substitution purpose of ordinary portland cement (OPC) in concrete [16]. The term was first introduced by Joseph Davidovits in the 1970s, although comparable materials were created in the previous Soviet Union since the 1950s, but were called soil cements [17].

The geopolymers are generally made of pozzolanic materials such as kaolin, metakaolin, GGBFS, fly ash and ceramic waste $[18,19]$. These materials are activated by an alkaline solution generally containing varying amounts of dissolved silicium [20]. They have a wide range of applications thanks to their properties such as resistance to acid attack, fire and high temperatures [21].

The main characteristic of geopolymers is their ability to provide an important reduction in $\mathrm{CO}_{2}$ emissions and less energy requirements for production compared with Ordinary Portland Cement products thanks to the low curing temperature used [20]. Geopolymers can be considered a green concrete [22].

Many work throught the literature, presented different technique of optimizing different aspect of the geopolymer formulation, from material composition to uses of recycled waste. Reig et al. [23] have shown that optimizing the type and concentration of the alkaline activator can produce mortar samples with a compressive strength up to $50 \mathrm{MPa}$ after 7 days of curing at $65^{\circ} \mathrm{C}$. Letelier et al. [24] studied the mechanical properties of concrete prepared with a combination of recycled aggregates and waste bricks. The combination of fly ash and waste bricks was presented by Rovanîk et al. [25]. Another study on the recycling of waste bricks and slag into new building material was presented by Zawrah et al. [26].

GGBFS is a waste produced by the iron blast furnace and subsequently tempered, and it is essentially composed by calcium alumino-silicate which is overload [26]. The GGBFS can be added to the geopolymer formulation since this component was proven to be one of the best activated materials, resulting in an increase in compressive strength and other mechanical properties $[27,28]$. The alkaline activation required for the geopolymerization process is generally provided by the addition of solutions such as sodium hydroxide and sodium silicate [29]. Theses study oriented the research on focusing on finding optimal ratio incorporated in the formulation of this geopolymer. Four properties were investigated by order of priority, compressive strength, incorporation of GGBFS, dissolution of hydroxide and the activator to hydroxide ratio.

The main objective of this research is to develop a new geopolymer for the building construction sector by using waste bricks as a solid precursor. In addition to waste bricks, other minerals are used for alkaline activation such as blast furnace slag and sand. Three properties 
were considered: the ratio of GGBFS/WB, the molarity of sodium hydroxide and the silicate to hydroxide ratio. The optimal value of each parameter was determined in this study. It should be noted that the preparation of geopolymer binder is not thermally activated. Thermal activation increases reactivity but also induces cost value, thus increases the economic cost of the material. Hence the importance of this work is to develop a new material at room temperature that can be a substitute for fired bricks. The scope of this research also includes the strength behavior for the mixtures of blast furnace slag and waste bricks alkali activated.

\section{Materials and methods}

\subsection{Materials}

The materials used in this experimental study are waste bricks (WB), sodium hydroxide $(\mathrm{NaOH})$, sodium silicate $\left(\mathrm{Na}_{2} \mathrm{SiO}_{3}\right)$, sand and ground granulated blast furnace slag (GGBFS).

The waste bricks and sand used in this work was supplied by the company BdN (Briqueterie du Nord) located in Lille (North of France). The waste bricks is crushed and sieved with the sand using a $400 \mu \mathrm{m}$ sieve.

The sand used in this preparation of geopolymer bricks was the same as the one used for the fired brick preparation of BDN. The choice was made to keep a uniform matrix as fired bricks made of clay and sand. The GGBFS was used based on composition and it is essentially composed of a balanced aluminosilicate matrix with a calcium overload. It is well known for incorporation into geopolymer systems to increase compressive strength and improve the development of resistance at room temperature [30]. The alkaline activator used in the preparation of geopolymer bricks is a combination of hydroxide and sodium silicate. This choices is intended to have a positive effect due to the small ionic size of $\mathrm{Na}^{+}$which makes it more active and promotes a better dissolution of the raw material [31]. Reactions occur at a high rate when the alkaline activator contains soluble silicate compared to using only a hydroxide solution [32]. Hence the combination of silicate and sodium hydroxide was used in the preparation of geopolymer bricks (Table 1).

\subsection{Chemical composition of solid materials}

The chemical composition of waste bricks, blast furnace slag and sand, was obtained using the S4 BRUCKER X-ray fluorescence dispersion spectrometry technique. Table 2 presents the chemical composition of WB, GGBFS, and sand used in the preparation of geopolymer brick.
Table 1 All abbreviated words used throughout the manuscript

\begin{tabular}{ll}
\hline Word & Abbreviation \\
\hline High density polyethylene & $\mathrm{HDPE}$ \\
Polyetylene & $\mathrm{PE}$ \\
Fly ash & $\mathrm{FA}$ \\
Waste brick & $\mathrm{WB}$ \\
Ground granulated blast furnace slag & $\mathrm{GGBFS}$ \\
Briqueterie du nord & $\mathrm{BdN}$ \\
Ordinary portland cement & $\mathrm{OPC}$ \\
Sodium hydroxide & $\mathrm{NaOH}$ \\
Sodium silicate & $\mathrm{Na}_{2} \mathrm{SiO}_{3}$ \\
\hline
\end{tabular}

Table 2 Chemical composition of waste bricks (WB), slag (GGBFS) and sand

\begin{tabular}{lcll}
\hline $\begin{array}{l}\text { Chemical composition } \\
\text { (wt\%) }\end{array}$ & $\mathrm{WB}$ & GGBFS & Sand \\
\hline $\mathrm{MgO}$ & 1.41 & 5.76 & 0.47 \\
$\mathrm{Al}_{2} \mathrm{O}_{3}$ & 12.68 & 9.16 & 5.57 \\
$\mathrm{SiO}_{2}$ & 73.106 & 33.84 & 89.99 \\
$\mathrm{~K}_{2} \mathrm{O}$ & 3.45 & 0.54 & 1.2 \\
$\mathrm{CaO}$ & 1.02 & 49.17 & 0.19 \\
$\mathrm{TiO}_{2}$ & 0.87 & 0.77 & 0.2 \\
$\mathrm{MnO}$ & 0.68 & 0.3 & 0.02 \\
$\mathrm{Fe}_{2} \mathrm{O}_{3}$ & 6.74 & 0.46 & 2.35 \\
$\mathrm{Ni}_{2} \mathrm{O}_{3}$ & 0.009 & - & 0.01 \\
$\mathrm{Cu}_{2} \mathrm{O}$ & 0.007 & - & - \\
$\mathrm{ZnO}^{\mathrm{GaO}_{3}}$ & 0.02 & - & - \\
\hline
\end{tabular}

The chemical composition of waste bricks indicates that the $\mathrm{SiO}_{2}$ content is $76.106 \%$ by mass against $12.68 \%$ by mass for $\mathrm{Al}_{2} \mathrm{O}_{3}$. The $\mathrm{SiO}_{2} / \mathrm{Al}_{2} \mathrm{O}_{3}$ molar ratio is 6 , which classify the waste bricks as siliceous material [33]. The GGBFS is composed by two majors parts: $33.84 \% \mathrm{SiO}_{2}$ and $49.17 \%$ $\mathrm{CaO}$ by mass, with a minority of $9.16 \% \mathrm{Al}_{2} \mathrm{O}_{3}$. $\mathrm{SiO}_{2}$ represents the major phase of sand with $89.99 \%$ of its chemical composition.

\subsection{Mineralogical characterization of solid materials}

The mineralogical composition was determined by X-ray diffraction analysis (XRD), using a D8 Advance BRUCKER AXS energy dispersive diffractometer as apparatus. This last composition makes possible the identification of different crystallized mineral phases in the sample.

Data in Fig. 1 show that quartz $\left(\mathrm{SiO}_{2}\right)$ is the main crystalline phase in the waste bricks. Calcite $(\mathrm{CaCO} 3)$ and 


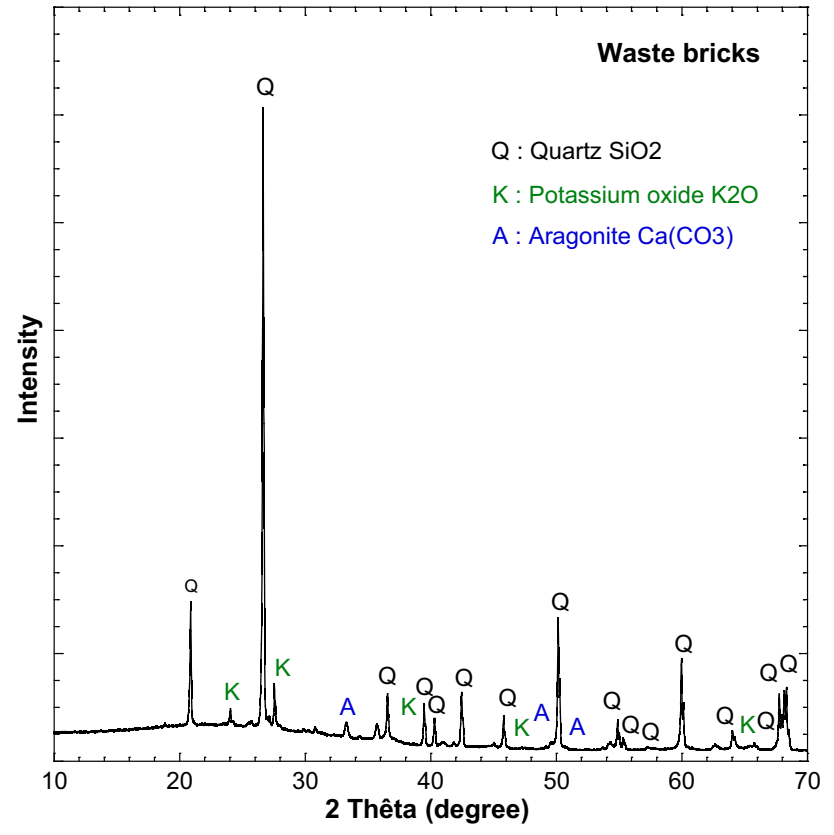

Fig. 1 XRD of waste bricks

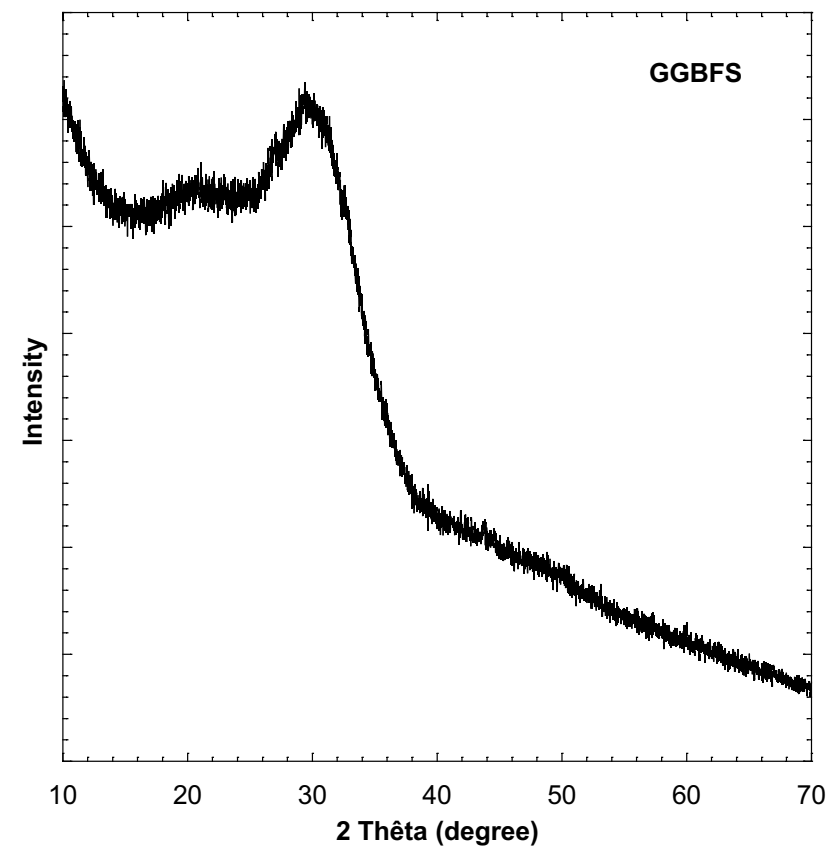

Fig. 2 XRD of GGBFS

potassium oxide $\left(\mathrm{K}_{2} \mathrm{O}\right)$ were also identified as minor constituents $[23,34]$.

Figure 2 illustrates the mineralogical composition of the GGBFS. Quartz $\left(\mathrm{SiO}_{2}\right)$ and calcium oxide $(\mathrm{CaO})$ are the main phases [35]. The amorphous hump displayed in the XRD analysis of the GGBFS indicates that a large amount of glass is present [36].

\subsection{Alkaline activators}

The combination of silicate and sodium hydroxide was used as an alkaline activator for the preparation of geopolymer bricks. Sodium silicate is composed of $27 \% \mathrm{SiO}_{2}$, $8 \% \mathrm{Na}_{2} \mathrm{O}$, and $65 \% \mathrm{H}_{2} \mathrm{O}$ (by mass) $[37,38]$. $\mathrm{NaOH}$ with a purity of $98 \%$ was supplied in solid capsules forms $[39,40]$. Sodium hydroxide is prepared in different concentrations of $6 \mathrm{M}, 8 \mathrm{M}, 10 \mathrm{M}, 12 \mathrm{M}$ and $14 \mathrm{M}$. The two solutions of $\mathrm{NaOH}$ and $\mathrm{Na}_{2} \mathrm{SiO}_{3}$ were mixed $24 \mathrm{~h}$ before the geopolymer bricks samples were prepared to obtain the homogeneity of the total solution.

\section{Experimental methods}

Geopolymer bricks were prepared by mixing the solid precursors: $50 \%$ sand and 50\% (WB and GGBFS) with an alkaline solution of silicate and sodium hydroxide. All the formulations prepared in our study contain $50 \%$ of sand by weight. The variation is reflected only in the percentages of WB and GGBFS. Various studies have shown that the order of preparation and the method of mixing materials have a very important role to play in achieving good results [21].

To obtain a homogeneous geopolymer binder, dry solid materials were mixed for $3 \mathrm{~min}$, then the alkaline solution were added, and the mixing remained for $6 \mathrm{~min}$ in order to get an homogenous binder. The liquid/solid ratio used is 0.4 by weight, using a mixer with a capacity of $5 \mathrm{I}$.

After mixing, five prismatic samples of $40 \times 40 \times 160 \mathrm{~mm}^{3}$ were molded for each formulation to measure flexural and compressive strengths. These numbers of samples were used to ensure the reproducibility of the strength testings. Hence, the means of the prepared samples are calculated.

In this study, geopolymer bricks are formulated according to the following three properties:

- The GGBFS to WB ratio;

- The molarity of $\mathrm{NaOH}$;

- The silicate to hydroxide $(\mathrm{S} / \mathrm{H})$ ratio of the alkaline solution.

\subsection{Preparation of samples with different GGBFS/ WB ratio}

The type of additives has a central influence on geopolymerization [41]. Several studies have shown that calcium accelerates the reaction of geopolymerization and increases the compressive strength of geopolymers [28, 42]. This increase is caused by the reaction of calcium compounds with the geopolymer binder. The results show that 
the inclusion of these additives in the binary mixed binder is effective in improving the mechanical performance of geopolymers based on waste bricks [43]. To optimize the GGBFS/WB ratio in the geopolymer formulation, the variation in compressive and flexural strengths, as a function of the GGBFS/WB ratio, was studied. The $40 \times 40 \times 160 \mathrm{~mm}^{3}$ prismatic samples are prepared according to different GGBFS/WB ratios, while the $\mathrm{NaOH}$ molarity and $\mathrm{Na}_{2} \mathrm{SiO}_{3} /$ $\mathrm{NaOH}$ mass ratio have been set at $10 \mathrm{M}$ and 2.5 respectively as highlighted in Table 2.

\subsection{Preparation of samples with different molarity of $\mathrm{NaOH}$}

The presence of a sufficient quantity of $\mathrm{NaOH}$ in the liquid phase have an essential role in the geopolymerization reaction [44]. $\mathrm{NaOH}$ reacts as a dissolving agent for aluminum and silicium [45]. Based on the literature, the range of molarity from 6 to $14 \mathrm{M}$ are used to optimize the maximum dissolution of the aluminosilicate material. To evaluate the effect of $\mathrm{NaOH}$ molarity on the compressive and flexural strengths, a series of $40 \times 40 \times 160 \mathrm{~mm}^{3} \mathrm{sam}$ ples of geopolymer bricks were prepared with a $\mathrm{Na}_{2} \mathrm{SiO}_{3} /$ $\mathrm{NaOH}$ mass ratio of 2.5 , a GGBFS/WB mass ratio $=80 / 20$, and with different molarities of $\mathrm{NaOH}$ as illustrated in the Table 2.

\subsection{Preparation of samples with variable silicate-to-hydroxide ratio $(\mathrm{S} / \mathrm{H})$}

The combination of sodium (or potassium silicate) and sodium hydroxide (or potassium hydroxide) is the most common alkaline liquid combination used for geopolymerization reactions [46]. Studies have shown that kinetics of these reactions and properties of geopolymers are affected by the $\mathrm{SiO}_{2} / \mathrm{Al}_{2} \mathrm{O}_{3}$ ratio and the $\mathrm{Na}-\mathrm{Si}-\mathrm{Al}$ bond formed [47]. Excess of $\mathrm{NaOH}$ in the mixture causes microcracks in the prepared geopolymer samples, and small amounts of $\mathrm{NaOH}$ is insufficient for silica leaching and alumina oxides in the geopolymerization reaction [48]. Therefore, to obtain the best geopolymerization results, it is necessary to optimize the silicate to hydroxide ratio used in the geopolymerization reaction. A final series of prismatic geopolymer bricks samples were prepared to optimize the silicate/hydroxide $(\mathrm{S} / \mathrm{H})$ ratio. These samples are prepared according to four formulations so that the GGBFS/WB ratio and $\mathrm{NaOH}$ molarity are fixed while the $\mathrm{S} / \mathrm{H}$ ratio is variable.

The GGBFS/WB ratio used was the optimum resulting from the first tests (GGBFS/WB $=80 / 20$ ), with the optimal molarity obtained for $\mathrm{NaOH}(\mathrm{NaOH} 8 \mathrm{M})$.
Table 3 presents the different samples prepared with the percentages of GGBFS, WB, the $\mathrm{NaOH}$ molarity and the $\mathrm{S} / \mathrm{H}$ ratio.

All prepared samples are named as follow GWB x/y-m-r, with:

- $x / y$ is the mass ratio GGBFS/WB, which ranges from $0 / 100$ to $100 / 0$.

- $m$ is the molarity of $\mathrm{NaOH}$, with $m=6,8,10,12$ or 14 .

- $r$ is the silicate/hydroxide mass ratio, with $r=1.5,2,2.5$ or 3.

\subsection{Sample's hardening properties and strength testing}

The hardening of samples is carried out according to a well-defined experimental protocol presented in Fig. 3 . The steps are as follow:

- $40 \times 40 \times 160 \mathrm{~mm}^{3}$ samples are demolded after $30 \mathrm{~min}$;

- During the first 4 days of curing, samples are left at room temperature (around $23^{\circ} \mathrm{C}$ ) and a relative humidity of $80 \%$, by using a saturated aqueous solution [49];

- Samples are put in the oven at $40{ }^{\circ} \mathrm{C}$ for 12 days at a relative humidity of $80 \%$ [49];

- Then, the temperature of curing is increased to $110^{\circ} \mathrm{C}$ for $12 \mathrm{~h}$.

Table 3 Properties of all prepared samples

\begin{tabular}{lccll}
\hline Samples & GGBFS (\%) & WB (\%) & $\begin{array}{l}\text { NaOH } \\
\text { molarity } \\
\text { (M) }\end{array}$ & S/H \\
\hline Optimization of the GGBFS/WB ratio & & & \\
GWB 100/0-10-2.5 & 100 & 0 & 10 & 2.5 \\
GWB 80/20-10-2.5 & 80 & 20 & 10 & 2.5 \\
GWB 60/40-10-2.5 & 60 & 40 & 10 & 2.5 \\
GWB 40/60-10-2.5 & 40 & 60 & 10 & 2.5 \\
GWB 20/80-10-2.5 & 20 & 80 & 10 & 2.5 \\
GWB 0/100-10-2.5 & 0 & 100 & 10 & 2.5 \\
Optimization of NaOH molarity & & & \\
GWB 80/20-6-2.5 & 80 & 20 & 6 & 2.5 \\
GWB 80/20-8-2.5 & 80 & 20 & 8 & 2.5 \\
GWB 80/20-10-2.5 & 80 & 20 & 10 & 2.5 \\
GWB 80/20-12-2.5 & 80 & 20 & 12 & 2.5 \\
GWB 80/20-14-2.5 & 80 & 20 & 14 & 2.5 \\
Optimization of the silicate-to-hydroxide ratio (S/H) & \\
GWB 80/20-8-1.5 & 80 & 20 & 8 & 1.5 \\
GWB 80/20-8-2 & 80 & 20 & 8 & 2 \\
GWB 80/20-8-2.5 & 80 & 20 & 8 & 2.5 \\
GWB 80/20-8-3 & 80 & 20 & 8 & 3 \\
\hline
\end{tabular}




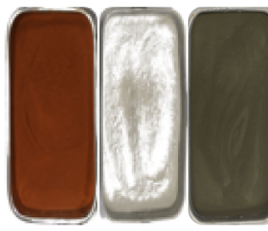

WB GGBFS Sand

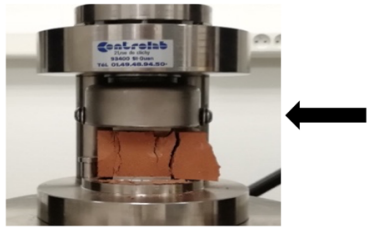

Compressive strength study

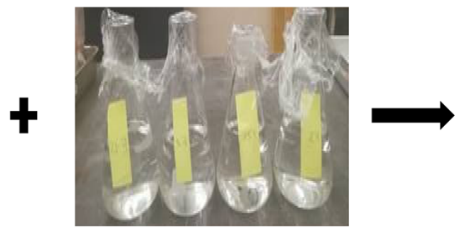

Silicate + sodium hydroxide

Alkaline activator

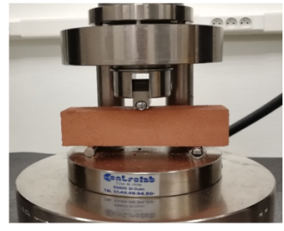

Flexural strength study

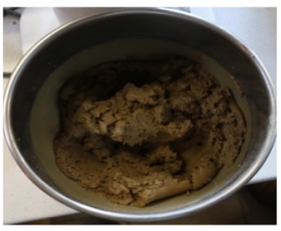

Geopolymer binder

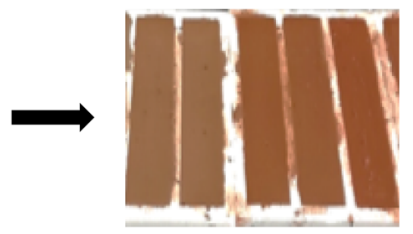

Mold of $4 \times 4 \times 16 \mathrm{~cm}^{3}$ samples

1

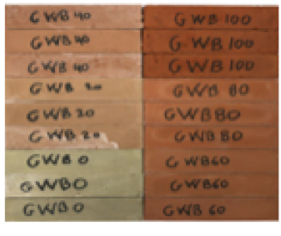

Geopolymer bricks samples

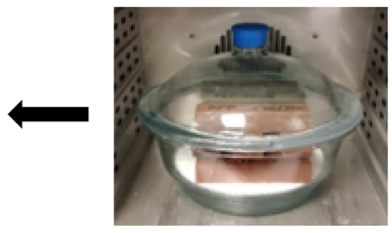

Samples curing

Fig. 3 Methodology of sample preparation, curing and strength testing

Finally, the flexural and compressive strengths are determined for these samples and the hardened properties of each sample type was measured as illustrated in the Fig. 3. The values shown in this study represent an average obtained from five geopolymer bricks samples. All these resistances have been evaluated according to NF P15-471-1 (for flexural) and NF EN 196-1 (for compression). For the flexural strength tests on prismatic samples, a multi-purpose test machine with a loading speed of $3 \mathrm{kN} /$ min was used. For compressive strength measurements on cubic samples, the same machine was used with a loading speed of $144 \mathrm{kN} / \mathrm{min}$.

\section{Results and discussion}

\subsection{GGBFS/WB ratio}

Figure 4 shows the variation of compressive and flexural strengths with GGBFS/WB ratio. The GGBFS/WB ratio $=0 / 100$, has a compressive strength of $38.51 \mathrm{MPa}$ which is higher than a traditional fired bricks [45].

However, compressive strength evolves with the increase in the percentage of GGBFS in the formulation of the geopolymer bricks studied. For a ratio GGBFS/ $W B=20 / 80$, the compressive strength is $39.65 \mathrm{MPa}$. This resistance increases to $57.96 \mathrm{MPa}$ for the ratio of GGBFS/ $W B=80 / 20$. Beyond this ratio, this resistance decreases to $50.58 \mathrm{MPa}$, for a GGBFS/WB $=100 / 0$ ratio. Therefore, the optimal ratio between blast furnace slag and waste bricks is $\mathrm{GGBFS} / \mathrm{WB}=80 / 20$.

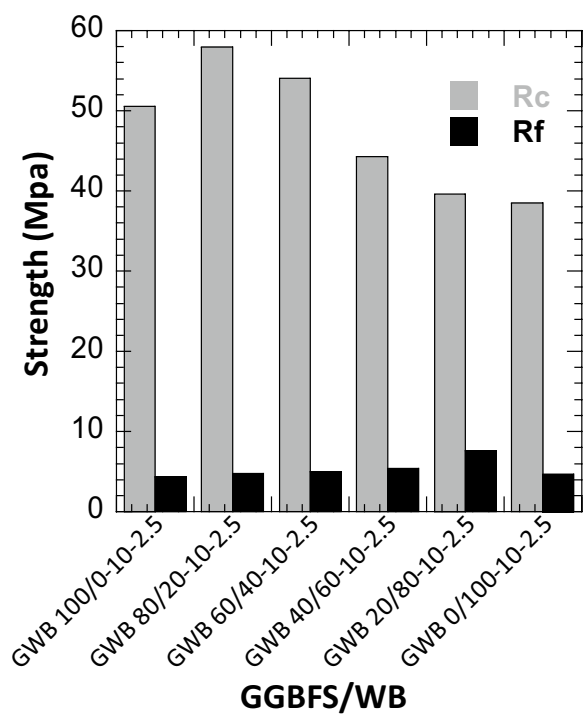

Fig. 4 Variation in compressive and flexural strength samples prepared with different GGBFS/WB ratios

The GGBFS $/ W B=20 / 80$ ratio gives the highest flexural strength value is 7.6 $\mathrm{MPa}$. Other flexural resistances are lower because of the presence of blast furnace slag, which results in rapid setting and leads to the formation of microcracks. When microcracks are identified, the propagation of the main crack caused by flexural is rapid. It can be noted that, with the increase in dosage of blast furnace slag, the flexural resistance decreases. The optimal flexural strength ratio of blast furnace slag and waste bricks is GGBFS/WB $=20 / 80$. 
The improvement in compressive strength is mainly due to the inclusion of blast furnace slag in the matrix, which leads to the reinforcement of the geopolymer binder. In addition, the amount of calcium oxide ( $\mathrm{CaO})$ contained in the ground granulated blast furnace slag precursor (GGBFS) was found to have a significant impact on the resulting cured geopolymer and therefore shows an improvement in the mechanical properties of the specimens [26].

\subsection{Effect of $\mathrm{NaOH}$ molarity}

Figure 5 highlights the effect of the molarity of $\mathrm{NaOH}$ ( $6 \mathrm{M}, 8 \mathrm{M}, 10 \mathrm{M}, 12 \mathrm{M}$ and $14 \mathrm{M}$ ) on the compressive and flexural strengths. The optimal compressive strength was obtained using $8 \mathrm{M} \mathrm{NaOH}$, with a value of 78.4 MPa. The lowest resistance was noticed at $47.61 \mathrm{MPa}$ for a molarity of $14 \mathrm{M}$. Formulations with $6 \mathrm{M}, 10 \mathrm{M}$ and $12 \mathrm{M}$ molarities have a moderate resistance, respectively $59.39 \mathrm{MPa}$, $57.96 \mathrm{MPa}$, and $51.69 \mathrm{MPa}$.

The optimal resistance is obtained using $8 \mathrm{M} \mathrm{NaOH}$, with a value of $6.21 \mathrm{MPa}$. For $6 \mathrm{M}$ and $10 \mathrm{M}$, we had respectively a flexural strength of $6.01 \mathrm{MPa}$ and $4.77 \mathrm{MPa}$. For both formulations with $12 \mathrm{M}$ and $14 \mathrm{M}$ molarities, the results reveal approximately the same resistances, respectively $3.13 \mathrm{MPa}$ and $3.12 \mathrm{MPa}$. Therefore, $\mathrm{NaOH} 8 \mathrm{M}$ is considered the optimal concentration for a maximum compressive and flexural strength.

These results are consistent with those of other researchers [50]. The molarity of $\mathrm{NaOH}$ has a significant effect as an activating solution on the mechanical strength of geopolymer samples. In the geopolymer reaction, the

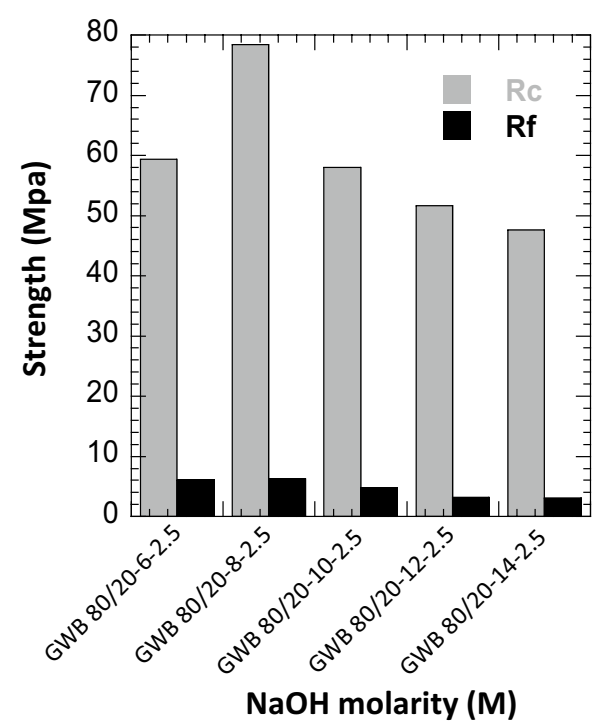

Fig. 5 Progression of compressive and flexural strength for samples prepared according to different molarities of $\mathrm{NaOH}$ increase in molarity will favour an acceleration of the reaction rate due to the increase in soluble silicate and the higher concentration of reagents [47]. The effect of $\mathrm{NaOH}$ on geopolymerization is explained by the greater dissolution of aluminosilicate minerals in the $\mathrm{NaOH}$ solution, thus a greater number of oligomers are formed and develop a higher compressive strength.

\subsection{Silicate/hydroxide ratio}

The evolution of compressive and flexural strengths with the $\mathrm{Na}_{2} \mathrm{SiO}_{3} / \mathrm{NaOH}$ ratio is provided by Fig. $6 . \mathrm{Na}_{2} \mathrm{SiO}_{3} /$ $\mathrm{NaOH}=2$ ratio gives the maximum compressive strength of $89.91 \mathrm{MPa}$. Whereas, for the other ratios of 1.5, 2.5 and 3, we have compressive strengths respectively of $83.19 \mathrm{MPa}$, 78.4 $\mathrm{MPa}$ and 70.4 $\mathrm{MPa}$. Therefore, the optimal ratio for compressive strength is $\mathrm{Na}_{2} \mathrm{SiO}_{3} / \mathrm{NaOH}=2$. Beyond this ratio the compressive strength decreases. This is explained by the two following cases:

- $\mathrm{Na}_{2} \mathrm{SiO}_{3} / \mathrm{NaOH}=1.5$, an insufficient of $\mathrm{NaOH}$ for the total dissolution of aluminosilicates and an excess of $\mathrm{Si}$ ions in the geopolymerization. It should be noted here that silica comes from two different sources, sodium silicate and the aluminosilicate material used. The results of this study show that the insufficient quantity of $\mathrm{Na}^{+}$ions and the unreacting excess of $\mathrm{Si}^{4+}$ ions have a negative reflection on the mechanical strength of cured geopolymers [26].

- $\mathrm{Na}_{2} \mathrm{SiO}_{3} / \mathrm{NaOH}=2.5$ and 3, excess of $\mathrm{Na}^{+}$in the geopolymerization. Thus, an excess of unreacted $\mathrm{Na}^{+}$ions

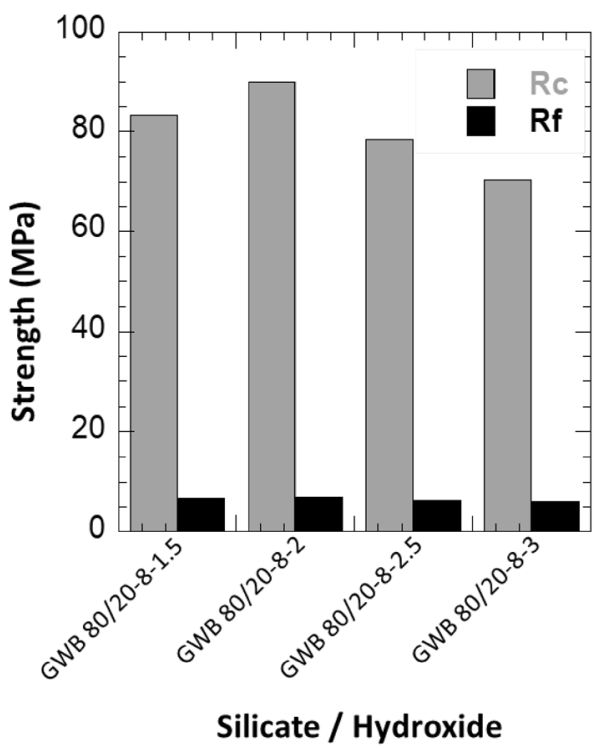

Fig. 6 Evolution of compressive and flexural strength for samples prepared according to different silicate/hydroxide ratios 
which have a negative effect on the mechanical properties of the geopolymer in the cured state.

The increase in the $\mathrm{Na}_{2} \mathrm{SiO}_{3} / \mathrm{NaOH}$ ratio increases the sodium content in the mixture. Sodium is important for the formation of geopolymers because it acts as charge balancing ions. However, compressive strength decreases as more silicate is added to the system because the excess sodium silicate prevents water evaporation and the formation of structures [51].

Figure 6 reveals that the ratio $\mathrm{Na}_{2} \mathrm{SiO}_{3} / \mathrm{NaOH}=2$ has the highest flexural strength value that reaches $6.94 \mathrm{MPa}$. The lowest resistance, $6.06 \mathrm{MPa}$, is given by $\mathrm{Na}_{2} \mathrm{SiO}_{3} / \mathrm{NaOH}$ ratio $=3$. Therefore, the optimal ratio of sodium silicate and sodium hydroxide is $\mathrm{Na}_{2} \mathrm{SiO}_{3} / \mathrm{NaOH}=2$ for flexural strength.

\subsection{Optimal formulation ratio}

Based on the result from the above formulation, a test with the optimal properties ( $8 \mathrm{M}$ molarity, $\mathrm{Na}_{2} \mathrm{SiO}_{3} / \mathrm{NaOH}=2$ ) was performed. This test confirms the optimization of the GGBFS/WB ratio in the geopolymer formulation. The compressive and flexural strengths increase with the optimal value of $\mathrm{NaOH}$ molarity $(8 \mathrm{M})$ and $\mathrm{Na}_{2} \mathrm{SiO}_{3} / \mathrm{NaOH}=2$ as shown in Fig. 7.

The GGBFS/WB ratio of $80 / 20$ gives the maximum compressive strength of $89.91 \mathrm{MPa}$. Whereas, for the other ratios of $100 / 0,60 / 40,40 / 60,20 / 80$ and $0 / 100$, we have respectively, 72.48 $\mathrm{MPa}, 79.2 \mathrm{MPa}, 51.92 \mathrm{MPa}, 44.78 \mathrm{MPa}$ and $38.96 \mathrm{MPa}$.

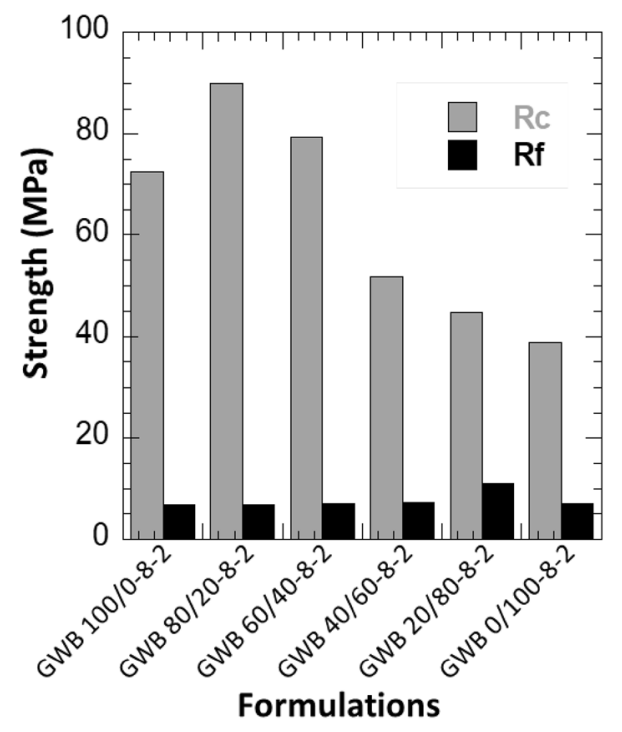

Fig. 7 Variation in compressive and flexural strength samples prepared with different GGBFS/WB ratios and optimal ratio of $\mathrm{NaOH}$ molarity $(8 \mathrm{M})$ and the silicate-to-hydroxide ratio $(\mathrm{S} / \mathrm{H}=2)$
The highest flexural strength value reaches $10.97 \mathrm{MPa}$ given by the formulation GWB 20/80-8-2.

The results of this study reveal that the compressive and flexural strengths of geopolymer bricks samples, increases with a certain amount increase of $\mathrm{CaO}$ related to the GGBFS in the formulation [42]. The maximum compressive strength obtained is $89.91 \mathrm{MPa}$ for the optimum value of $\mathrm{CaO}$ in the formulation GWB 80/20-8-2. Beyond this value of $\mathrm{CaO}$ the compressive strength starts to decrease. While, for the flexural resistance, the results noted that the increase occurs with the increase of the percentage of waste bricks in the geopolymer formulation. The maximum value obtained is $10.97 \mathrm{MPa}$ for the formulation WB 20/80-8-2 and beyond this value, the flexural resistance decreases.

\subsection{Future implementation of geopolymer bricks and recommendations}

The analyses and results of this study have shown that geopolymer bricks can replace fired bricks. Future research should focus on studying the durability of this geopolymer material and the method of integrating this new generation of materials into the brick's production line. A study is being carried out on the change required in the fired brick production chain to integrate geopolymer bricks. For this practical application, several recommendations must be considered. Starting with a comparison of the life cycle phases of the two types of bricks. Then, a detailed study on the preparation of raw materials and completing it with the process of preparation and drying of geopolymer bricks at the industrial level.

\section{Conclusion}

This research focuses on the potential for reuse of industrial waste for the production of geopolymer-based building materials. The article presents an experimental study of waste brick recycling with the association of another industrial waste, ground granulated blast furnace slag, to produce a new geopolymer brick. The process of preparing the geopolymer bricks was carried out using a combination of hydroxide and sodium silicate as an alkaline solution. The quantity of GGBFS incorporated, the molarity of $\mathrm{NaOH}$ and the silicate/hydroxide ratio are the three parameters that each been optimised according to the mechanical strength of the final product. The results of this study highlight and demonstrate a new and advantageous application in the construction of a major waste with the geopolymerization process. These results show that the inclusion of ground granulated blast furnace slag (GGBFS) in the geopolymer matrix based on brick waste 
(WB) improves the physical and mechanical properties of the geopolymer brick. The best compressive strength of 89.91 MPa was obtained for a ratio of GGBFS/WB $=80 / 20$, a silicate to hydroxide ratio $=2$ and a molarity of $8 \mathrm{M}$ $\mathrm{NaOH}$. The highest bending strength obtained in this study is $10.97 \mathrm{MPa}$ for a GGBFS/WB $=20 / 80$ ratio, a silicate to hydroxide ratio $=2$ and a molarity of $8 \mathrm{M} \mathrm{NaOH}$. This research therefore concludes that geopolymer bricks are an environmentally friendly alternative to conventional fired bricks.

Acknowledgements The author also recognizes the support of the brickworks of the north of France $(\mathrm{BdN})$ for the donation of waste bricks and sand, respectively in this study.

\section{Compliance with ethical standards}

Conflict of interest This research study was followed by another study on the environmental impact of geopolymer bricks. This work presented the calculation of the $\mathrm{CO}_{2}$ equivalent of geopolymer bricks in order to compare it with the existing fired brick. The different formulations of geopolymer bricks based on waste bricks have shown a $\mathrm{CO}_{2}$ reduction of around $31 \%$ compared to fired bricks.

\section{References}

1. Kadir AA, Mohajerani A (2011) Bricks: an excellent building material for recycling wastes-a review. In: Environmental management and engineering conference (EME 2011), Calgary, Canada, July 4-6, pp 108-115

2. Puertas $F$ (2015) Waste glass in the geopolymer preparation. Mechanical and microstructural characterisation. J Clean Prod 90:397-408. https://doi.org/10.1016/j.jclepro.2014.11.074

3. Sellakutty D (2016) Utilisation of waste plastic in manufacturing of bricks and paver blocks. Int J Appl Eng Res 11:364-368

4. Cheng $\mathrm{H}$ (2016) Reuse research progress on waste clay brick. Procedia Environ Sci 31:218-226. https://doi.org/10.1016/j. proenv.2016.02.029

5. Fernández-Jiménez A, Palomo A, Pastor JY, A Martin (2008) New cementitious materials based on alkali-activated fly ash: performance at high temperatures. J Am Ceram Soc 91:3308-3314. https://doi.org/10.1111/j.1551-2916.2008.02625.x

6. Roy DM (1999) Alkali-activated cements opportunities and challenges. Cem Concr Res 29:249-254

7. Zhang $L$ (2013) Production of bricks from waste materials-a review. Constr Build Mater 47:643-655. https://doi. org/10.1016/j.conbuildmat.2013.05.043

8. Akhtar A, Sarmah AK (2018) Construction and demolition waste generation and properties of recycled aggregate concrete: a global perspective. J Clean Prod 186:262-281. https://doi. org/10.1016/j.jclepro.2018.03.085

9. Black L (2014) Low clinker cement as a sustainable construction material. University of Leeds, Leeds

10. Diaz El, Allouche EN, Eklund S (2010) Factors affecting the suitability of fly ash as source material for geopolymers. Fuel 89:992-996. https://doi.org/10.1016/j.fuel.2009.09.012

11. Sutcu M, Alptekin H, Erdogmus E, Er Y, Gencel O (2015) Characteristics of fired clay bricks with waste marble powder addition as building materials. Constr Build Mater 82:1-8. https://doi. org/10.1016/j.conbuildmat.2015.02.055
12. Eliche-Quesada D, Sandalio-Pérez JA, Martínez-Martínez $S$, Pérez-Villarejo L, Sánchez-Soto PJ (2018) Investigation of use of coal fly ash in eco-friendly construction materials: fired clay bricks and silica-calcareous non fired bricks. Ceram Int 44:4400-4412. https://doi.org/10.1016/j.ceramint.2017.12.039

13. Monteiro SN, Vieira CMF (2014) On the production of fired clay bricks from waste materials: a critical update. Constr Build Mater 68:599-610. https://doi.org/10.1016/j.conbuildma t.2014.07.006

14. Pacheco-Torgal F, Jalali S (2010) Reusing ceramic wastes in concrete. Constr Build Mater 24:832-838. https://doi.org/10.1016/j. conbuildmat.2009.10.023

15. Davidovits J (1991) Geopolymers-inorganic polymeric new materials. JTherm Anal 37:1633-1656. https://doi.org/10.1007/ BF01912193

16. Davidovits PJ (2002) 30 years of successes and failures in geopolymer applications. Market trends and potential breakthroughs. In: Geopolymer 2002 conference, Melbourne, Australia, October 28-29, pp 1-16

17. Dutt KS, Kumar KV, Kishore IS, Chowdary CM (2016) A case study on fly ash based geo-polymer concrete. Int J Eng Trends Technol 34:58-62

18. Khale D, Chaudhary R (2007) Mechanism of geopolymerization and factors influencing its development: a review. J Mater 42:729-746. https://doi.org/10.1007/s10853-006-0401-4

19. Davidovits J (1994) Properties of geopolymer cements. In: First international conference on alkaline cements concretes, pp 131-149

20. Komnitsas K, Zaharaki D (2007) Geopolymerisation: a review and prospects for the minerals industry. Miner Eng 20:1261-1277. https://doi.org/10.1016/j.mineng.2007.07.011

21. Pacheco-torgal F (2008) Alkali-activated binders: a review. Part 2. About materials and binders manufacture. Constr Build Mater 22:1315-1322. https://doi.org/10.1016/j.conbuildma t.2007.03.019

22. He J, Zhang J, Yu Y, Zhang G (2012) The strength and microstructure of two geopolymers derived from metakaolin and red mud-fly ash admixture: a comparative study. Constr Build Mater 30:80-91. https://doi.org/10.1016/j.conbuildmat.2011.12.011

23. Reig L, Tashima MM, Borrachero MV, Monzó J, Cheeseman CR, Payá J (2013) Properties and microstructure of alkali-activated red clay brick waste. Constr Build Mater 43:98-106. https://doi. org/10.1016/j.conbuildmat.2013.01.031

24. Letelier V, Tarela E, Moriconi G (2017) Mechanical properties of concretes with recycled aggregates and waste brick powder as cement replacement. Procedia Eng 171:627-632. https://doi. org/10.1016/j.proeng.2017.01.396

25. Rovnaník P, Rezník B, Rovnaníková P (2016) Blended alkali-activated fly ash/brick powder materials. Procedia Eng 151:108-113. https://doi.org/10.1016/j.proeng.2016.07.397

26. Zawrah MF, Gado RA, Feltin N, Ducourtieux S, Devoille L (2016) Recycling and utilization assessment of waste fired clay bricks (Grog) with granulated blast-furnace slag for geopolymer production. Process Saf Environ Prot 103:237-251. https://doi. org/10.1016/j.psep.2016.08.001

27. Hu S, Wang H, Zhang G, Ding Q (2008) Bonding and abrasion resistance of geopolymeric repair material made with steel slag. Cem Concr Compos 30:239-244. https://doi.org/10.1016/j. cemconcomp.2007.04.004

28. Nath P, Sarker PK (2014) Effect of GGBFS on setting, workability and early strength properties of fly ash geopolymer concrete cured in ambient condition. Constr Build Mater 66:163-171. https://doi.org/10.1016/j.conbuildmat.2014.05.080

29. Duxson P, Mallicoat SW, Lukey GC, Kriven WM, van Deventer JSJ (2007) The effect of alkali and Si/Al ratio on the development of mechanical properties of metakaolin-based geopolymers. 
Colloids Surf A Physicochem Eng Asp 292:8-20. https://doi. org/10.1016/j.colsurfa.2006.05.044

30. Davidovits J, Sawyer J (1985) Early high-strength mineral polymer, no 4, pp 509-598

31. Panias D, Giannopoulou I (2009) Polymerization in sodium silicate solutions: a fundamental process in geopolymerization technology. J Mater Sci 44:3719-3730. https://doi.org/10.1007/ s10853-009-3497-5

32. Motorwala A, Shah V, Kammula R, Nannapaneni P, Raijiwala PDB (2013) Alkali activated fly-ash based geopolymer concrete. Int J Emerg Technol Adv Eng 3:159-166

33. Tiffo E, Elimbi A, Manga JD, Tchamba AB (2015) Red ceramics produced from mixtures of kaolinite clay and waste glass. Braz J Sci Technol 4:1-13. https://doi.org/10.13140/RG.2.1.1235.3760

34. Lavat AE, Trezza MA, Poggi M (2009) Characterization of ceramic roof tile wastes as pozzolanic admixture. Waste Manag 29:16661674. https://doi.org/10.1016/j.wasman.2008.10.019

35. Jeong Y, Eun J, Jun Y, Park J, Ha J (2016) In fluence of four additional activators on hydrated-lime $\left[\mathrm{Ca}(\mathrm{OH})_{2}\right]$ activated ground granulated blast-furnace slag. Cem Concr Compos 65:1-10. https://doi.org/10.1016/j.cemconcomp.2015.10.007

36. Durmus H, Erdemir M (2016) Microstructural alteration of alkali activated slag mortars depend on exposed high temperature level. Constr Build Mater 104:169-180. https://doi.org/10.1016/j. conbuildmat.2015.12.070

37. Sayed M, Zeedan SR (2013) Green binding material using alkali activated blast furnace slag with silica fume. HBRC J 8:177-184. https://doi.org/10.1016/j.hbrcj.2012.10.003

38. Tashima MM, Akasaki JL, Castaldelli VN, Soriano L, Monzó J, Payá J, Borrachero MV (2012) New geopolymeric binder based on fluid catalytic cracking catalyst residue (FCC). Mater Lett 80:5052. https://doi.org/10.1016/j.matlet.2012.04.051

39. Kumar Patra A, Chowdhry M, Prusty BK (2011) Effect of synthesis parameters on the compressive strength of fly ash based geopolymer concrete. Int J Environ Pollut Control Manag 3:79-88

40. Tashima MM, Akasaki JL, Melges JLP, Soriano L, Monzó J, Payá J, Borrachero MV (2013) Alkali activated materials based on fluid catalytic cracking catalyst residue (FCC): influence of $\mathrm{SiO}_{2} / \mathrm{Na}_{2} \mathrm{O}$ and $\mathrm{H} 2 \mathrm{O} / \mathrm{FCC}$ ratio on mechanical strength and microstructure. Fuel 108:833-839. https://doi.org/10.1016/j.fuel.2013.02.052

41. Bernal SA, Rodríguez ED, Mejia De Gutiérrez R, Provis JL, Delvasto $S$ (2012) Activation of metakaolin/slag blends using alkaline solutions based on chemically modified silica fume and rice husk ash. Waste Biomass Valoriz 3:99-108. https://doi. org/10.1007/s12649-011-9093-3

42. Temuujin J, van Riessen A, Williams R (2009) Influence of calcium compounds on the mechanical properties of fly ash geopolymer pastes. J Hazard Mater 167:82-88. https://doi.org/10.1016/j. jhazmat.2008.12.121

43. Nath P, Sarker PK, Rangan VB (2015) Early age properties of lowcalcium fly ash geopolymer concrete suitable for ambient curing. In: Procedia engineering, the 5th international conference of euro Asia civil engineering forum (EACEF-5), vol 125. Elsevier, Amsterdam, pp 601-607

44. McCarter WJ, Chrisp TM, Starrs G (1999) Early hydration of alkaliactivated slag: developments in monitoring techniques. Cem Concr Compos 21:277-283. https://doi.org/10.1016/S0958 -9465(99)00007-4

45. Ahmari S, Zhang L (2012) Production of eco-friendly bricks from copper mine tailings through geopolymerization. Constr Build Mater 29:323-331. https://doi.org/10.1016/j.conbuildma t.2011.10.048

46. Sanni SH, Khadiranaikar RB (2012) Performance of geopolymer concrete under severe environmental conditions. J Int Civ Eng Struct 3:396-407. https://doi.org/10.6088/ijcser.201203013037

47. De Silva P, Sagoe-Crenstil K, Sirivivatnanon V (2007) Kinetics of geopolymerization: role of $\mathrm{Al}_{2} \mathrm{O}_{3}$ and $\mathrm{SiO}_{2}$. Cem Concr Res 37:512-518. https://doi.org/10.1016/j.cemconres.2007.01.003

48. Suksiripattanapong $C$, Horpibulsuk $S$, Boongrasan $S$, Udomchai A, Chinkulkijniwat A, Arulrajah A (2015) Unit weight, strength and microstructure of a water treatment sludge-fly ash lightweight cellular geopolymer. Constr Build Mater 94:807-816. https://doi.org/10.1016/j.conbuildmat.2015.07.091

49. Greenspan $L$ (2012) Humidity fixed points of binary saturated aqueous solutions. J Res Natl Bur Stand Sect A Phys Chem 81A:89. https://doi.org/10.6028/jres.081a.011

50. Kabir SMA, Alengaram UJ, Jumaat MZ, Sharmin A, Islam A (2015) Influence of molarity and chemical composition on the development of compressive strength in POFA based geopolymer mortar. Adv Mater Sci Eng 2015:1-15. https://doi. org/10.1155/2015/647071

51. Morsy MS, Alsayed SH, Al-Salloum Y, Almusallam T (2014) Effect of sodium silicate to sodium hydroxide ratios on strength and microstructure of fly ash geopolymer binder. Arab J Sci Eng 39(6):4333-4339. https://doi.org/10.1007/s13369-014-1093-8

Publisher's Note Springer Nature remains neutral with regard to jurisdictional claims in published maps and institutional affiliations. 